\title{
ROYAL AERONAUTICAL SOCIETY
}

In view of doubts which appear to exist as to the qualifications required from candiclates for Associate Fellowship of the Royal Aeronautical Society, the Council consider it advisable to issue the following statement as to their interpretation of the regulations.

The regulations provide for the election to Associate Fellowship of :-

(a) Those who pass the Society's own examination, or possess an equivalent University or Technical College qualification, followed by two years' practical experience in the application of the science of aeronautics.

(b) Those who present a thesis.

(c) Those who have very exceptional qualifications or achievements but do not possess the examination qualifications outlined in $(a)$.

In regard to (a) the Council accept the degree or diploma of any recognised University or lechnical College at home or abroad, and excuse from the Aerodynamics paper of the Society's own examination holders of Diplomas in Aeronautics of such Universities or Technical Colleges.

In regard to $(b)$ the Council do not insist upon a thesis necessarily being a record of original work, but require it to be of such a nature as to give an. adequate idea of the candidate's knowledge and experience in aeronautics or an allied subject applied to ieronautics.

Under the heading $(c)$ the Council have accepted pilots of rigid airships, and aeroplane test and experimental pilots whose work has been, or is likely to be, of value to the progress of technical development. They also have accepted long-standing workers in any branch of aeronautics whose experience entitles them to be considered as "pioneers." In considering applications under this heading it is not possible to lay down any hard and fast rule, but each case must be considered individually on its merits.

The Council have also decided to publish the following correspondence bearing on the subject :--

To The SEchetary, I 1 th November, 1924 .

Royal Alironautical, Society.

DEAR Sur,-I have to thank you for your letter of the $17^{\text {th }}$ inst. containing an invitation to become a member of your Society. In reply, might I put before you a case which is not peculiar but common and will explain why I am not a member of that Society.

In the aircraft industry to-day there are a number of men of not inconsiderable experience... who have not attained to positions of any great responsibility but on whom, as section leaders and senior draughtsmen, the designer must depend to a large extent for the detail design and in a large number of cases the preliminary designs and performance calculations. Most of these men could and would design a machine should the opportunity present itself.

When, in its younger days, the Society offered to them facilities for becoming Associate Fellows, these men, for a multiplicity of reasons, let the opportunity slip. . . . Now that we would become Associate Fellows we find our way barred by an entrance examination which, to a man who has left school or college 15 or 20 years, appears quite formidable in its subjects. This same examination, however, permits the youth leaving college and having studied for three years 
with this end in view to become an Associate Fellow. When it comes down to bed rock, the youth works under such men as those of whom I write and it will be years (judging from my experience) before this same youth will be able to occupy the section leader's position.

In other words, the Society is, at present, ignoring the men who have acquired their knowledge from experience and supporting the theorist who has gained his knowledge from his tutor. . . .

Yours faithfully,

Royal Aeronautical Society,

$$
\begin{aligned}
& \text { 7, Albemarle Street, London, W. I, } \\
& \text { 2 rst November, } 1924 .
\end{aligned}
$$

DEAR SIR, - I beg to thank you for your letter which raises an interesting question and which 1 should like, with your permission, to lay before the Council.

In the meantime, however, I should like to make one or two observations personally. In the first place it is not quite accurate, I think, to say that a youth leaving college with purely theoretical qualifications is at once entitled to become an Associate Fellow, as the Council insist upon a further qualification of two years' practical experience.

Secondly, the Council have the power in exceptional cases to accept as Associate Fellows individuals who do not possess the necessary exempting qualifications without calling upon them to pass the examination; while there is, of course, the further alternative of the presentation of a thesis.

These points, at any rate to some extent, deal with the grievance you suggest, and of course the Council always view with considerable sympathy applications from people such as those you write about, who have been engaged upon aeronautics for a long time and therefore come within the category of Pioneers. On the other hand, the aim is to raise Associate Fellowship to the same standard as other bodies, such as the Institution of Civil Engineers, and therefore it is quite obvious that considerable technical qualifications and/or experience must be insisted on.

Yours faithfully,

(Signed) W. LockWOOD Marsir, Secretary.

To the Secretary, $23^{r d}$ November, 1924 .

Royal Aeronautical Society.

DEAR SIR,-Your letter and enclosure to hand and for which I thank you. . . .

I read with interest your remarks re qualifications and must admit that $\mathbf{I}$ forgot the extra qualification of two years' experience. This does not, I think, materially alter the case I put forward.

Taking the thesis qualification, I should say that it could not apply to such men as those of whom I wrote. A thesis, as I regard it, to be of any practical use, must be a mathematical exposition of some more or less advanced theory on which the writer of the thesis has carried out some special research work. You will, of course, agree with me that such is impossible to us, whose duty it is, not to form and prove theories, but rather to be able to apply the results of other people's experiments to the actual machine. It is in this way that the Society is of such great use to us-we are able to get the results of experiments carried out by abler men and be prepared to apply them when necessary. Many 
points are cleared up in the following discussions which would otherwise be left rather vague if the paper is merely read at home.

Our case then must be the claim.of "Pioneers." . . . If your Council could be prevailed upon to give some definite length of experience as representing that of a pioneer then the whole case would be perfectly clear.

I hope I am not asking too much in hoping that you will be good enough to acquaint me with the decision of your Council before completing my proposal form.

Yours faithfully,

Royal, Alenofactical Society,

7, Aibemarle Street, London, W.i, Ioth December, 1924 .

DEAR Silh, - In further reference to my previous correspondence with you, I laid this before the Council at their meeting yesterday. . . The Council confirmed the views expressed in my letter of the 2 ist November, but desired me to point out with reference to your letter of the 23 rd November that you take a somewhat too narrow view of the type of thesis required. It is not at all necessary that such a thesis should be either mathematical or an account of some special research work. All that is required is such a paper as will enable them to judge the qualifications of the writer, and this might take the form, for example, of an account of the method of application of (to use your own words) "the results of other people's experiments to the actual machine."

They also wished me to say that they think it very possible that if such people as you refer to would fill in application forms they would prove acceptable as Associate Fellows; but that, of course, any individual case of an application unaccompanied by any examination qualifications or a thesis would necessarily have to be considered on its own special merits.

I may also say that the Council propose to issue a statement early in the new year explaining in detail the manner in which they interpret the regulations, somewhat on the lines of our correspondence.

Yours faithfully,

(Signed) W. Lockwood Marsh,

Secretary. 